\title{
First approach to molecular epidemiology of bovine tuberculosis in Colombia
}

\section{Primera aproximación a la epidemiología molecular de la tuberculosis bovina en Colombia}

\author{
Jimena Jojoa-Jojoa, M.Sc, Maira Wintaco M, ${ }^{1}$ M.Sc, Francisco Osorio R, ${ }^{2}$ MV, \\ Gloria Puerto-Castro, ${ }^{1 *}$ M.Sc, Martha Guerrero-Guerrero, ${ }^{1}$ Bact.
}

\begin{abstract}
${ }^{1}$ Instituto Nacional de Salud, Dirección de Investigación en Salud Pública, Grupo de Micobacterias, Avenida Calle 26 \# 51-20 Bogotá D.C. Colombia. 2Instituto Colombiano Agropecuario ICA, Programa de Brucelosis y Tuberculosis bovina, Carrera 41 \# 17-81 Bogotá D.C. Colombia. ${ }^{*}$ Correspondencia: gpuerto@ins.gov.co
\end{abstract}

Received: March 2015; Accepted:June 2015.

\begin{abstract}
Objective. To investigate the presence of Mycobacterium bovis and other Mycobacterium species in samples of cattle and buffalo in Colombia, to start the molecular characterization of M. bovis in the country. Material and methods. 492 samples were collected from herds identified with the presence of infected animals through the PPD, by the Group of Bovine Tuberculosis ICA Colombian Agricultural Institute in eight departments of Colombia. Lymph nodes of head, thorax and abdomen, gross lesions of tissues with tuberculosis, nasal swabs, milk, blood and fresh cheeses were included. Samples were subjected to detection of Mycobacterium bovis and other mycobacteria by conventional microbiological analysis and PCR-6110 and spoligotyping molecular assays. Results. In the samples analyzed especially in lymph nodes, Mycobacterium bovis was demonstrated with genotypes reported and not previously reported in the world, as well as M. tuberculosis in Antioquia, Cundinamarca, Boyacá and Magdalena departments. Conclusions. In Colombia there are at least 7 genotypes of $M$. bovis that are infected and sick cattle and buffalo from four different departments becoming serious threat to public health.
\end{abstract}

Key words: Bovine tuberculosis, Mycobacterium bovis, diagnostic, molecular epidemiology, zoonosis (Sources: DeSC, MeSH).

\section{RESUMEN}

Objetivo. Investigar la presencia de Mycobacterium bovis y otras especies de Mycobacterium en muestras de ganado bovino y búfalino en Colombia e iniciar la caracterización molecular de M. bovis en el país. Materiales y métodos. 492 muestras fueron recogidas de hatos identificados con presencia de animales infectados a través de la prueba de PPD, por el Grupo de Tuberculosis Bovina del Instituto Colombiano Agropecuario ICA en ocho departamentos de Colombia. Se incluyeron ganglios linfáticos de cabeza, tórax y abdomen, tejidos con lesiones macroscópicas de tuberculosis, hisopos nasales, leche, sangre y quesos frescos. Las muestras se sometieron a investigación de Mycobacterium bovis y otras micobacterias mediante el análisis microbiológico convencional y pruebas moleculares de PCR-IS6110 y spoligotyping. Resultados. En las muestras analizadas especialmente en los ganglios linfáticos, se evidenció Mycobacterium bovis con genotipos reportados y no reportados previamente en el mundo, así como $M$. tuberculosis en los departamentos de Antioquia, Cundinamarca, Magdalena y Boyacá. Conclusiones. En Colombia existen al menos 7 genotipos de $M$. bovis que se encuentran infectando y enfermando a bovinos y bufalinos de cuatro diferentes departamentos del país constituyéndose en seria amenaza para la salud pública.

Palabras clave: Tuberculosis bovina, Mycobacterium bovis, diagnóstico, epidemiología molecular, zoonosis (Fuentes: DeSC, MeSH). 


\section{INTRODUCTION}

Mycobacterium bovis, the causative agent of tuberculosis in cattle, is also a pathogen for large numbers of animals as wild cats, domestic animals and human or nonhuman primates among others; therefore is considered an important zoonotic agent (1). Although $M$. tuberculosis is the most common etiologic agent of human tuberculosis, this can also be caused by Mycobacterium bovis, the main etiological agent of bovine tuberculosis; hence the importance in knowledge the distribution of this pathogen in the cattle and the identification of other potential reservoirs in Colombia in order to contribute to public health policies in the country, considering that described multiple cases of human tuberculosis caused by $M$. bovis and multiresistant $M$. bovis in HIV infected patients in the world (2).

In the industrialized countries, the incident of bovine tuberculosis in animals and human beings has diminished with the pasteurization processes of milk and the judicious managing of the programs of elimination. Meanwhile, into developing countries the bovine tuberculosis has a significant impact owed probably to the generalized lack of pasteurization process for the country and absence of documentation on the sanitary condition of the production lines bovine (3).

In Colombia, the Colombian Agricultural Institute ICA, within the program of eradication of tuberculosis and brucellosis, has established the use of tuberculin (PPD) or derivative protean purified, for the diagnosis of the bovine tuberculosis in these animals. This program has normalized that the animals with positive PPD must be sacrificed, whereas the cattle estates with two negative results in the consecutive years must be declared like free of tuberculosis by ICA (4).

Although the PPD is a good tool to identify positives cattles for $M$. bovis and initiate the sanitation of farms for the control and eradication of bovine tuberculosis, this test has limitations in sensitivity and specificity and therefore may show false positive, generating economic losses $(5,6)$. This joined the national epidemiological and economic context, is essential improve, simplify and extend the diagnosis using more sensitive and specific tests, indicate that with greater certainty about the behaviors continue to animals, to contribute to the eradication of the disease, as well and the saving of resources within the National Program of Bovine Tuberculosis Eradication (7).

\section{INTRODUCCIÓN}

Mycobacterium bovis, agente causal de la tuberculosis en el ganado, es también un patógeno para gran número de animales como los felinos silvestres, animales domésticos y primates humanos y no humanos, entre otros, por lo cual es considerado un agente zoonótico importante (1). Aunque M. tuberculosis es el agente etiológico más frecuente de la tuberculosis humana, ésta también puede ser producida por M. bovis; de ahí la importancia en el conocimiento de la distribución de éste patógeno en el ganado, así como la identificación de otros posibles reservorios en Colombia, con el fin de contribuir a las políticas de salud pública en el país; teniendo en cuenta que se han descrito varios casos de tuberculosis humana causada por $M$. bovis y $M$. bovis multirresistente en pacientes infectados con VIH en el mundo (2).

En los países industrializados la incidencia de tuberculosis bovina en animales y humanos ha disminuido por los procesos de la pasteurización de la leche y el manejo adecuado de los programas de eliminación. Mientras tanto, en los países en vía de desarrollo la tuberculosis bovina tiene un mayor impacto, debido probablemente a la carencia de procesos de pasteurización generalizados para el país y a la ausencia de documentación sobre el estado sanitario de las cadenas de producción bovina (3).

En Colombia el Instituto Colombiano Agropecuario ICA, dentro del programa de erradicación de la tuberculosis y la brucelosis, tiene establecido el uso de la tuberculina (PPD) o derivado proteico purificado, para el diagnóstico de la tuberculosis bovina en estos animales. Este programa establece que los animales PPD positivos deben ser sacrificados y las fincas puestas en cuarentena, mientras que las fincas ganaderas con animales PPD negativos en dos años consecutivos, son declaradas como libres de tuberculosis por el ICA (4).

Aunque la PPD es una herramienta que permite identificar animales positivos para M. bovis y así iniciar el saneamiento de las fincas para el control y erradicación de la tuberculosis bovina, esta prueba presenta limitaciones de sensibilidad y especificidad y por lo tanto puede mostrar falsos positivos; generando pérdidas económicas (5, 6). Lo anterior unido al contexto epidemiológico y económico nacional, hace prioritario mejorar, simplificar y extender el diagnóstico usando pruebas más sensibles y específicas, que con mayor especificidad indiquen sobre las conductas a seguir con los animales, para contribuir con la erradicación de la enfermedad, así como al ahorro de recursos en el marco del Programa Nacional de Erradicación de Tuberculosis Bovina (7). 
In Colombia, the prevalence of bovine tuberculosis detected postmortem is inaccurate and the number of farms officially certified since free of tuberculosis, has increased dramatically in the last years (4). In 2014, Colombia produced 6.717 million liters of milk and more than 837 million kilograms of beef (8), which meant a high proportion of revenue of currencies for the nation, therefore, a better knowledge and documentation of the situation of bovine tuberculosis it becomes necessary in order to adapt and to improve the epidemiological vigilance of this pathology guaranteeing the free revenue of the colombian products to the world markets (7).

In the field of the microbiological diagnosis of the bovine tuberculosis, this is delayed and costly, and is known that the excretion of the Mycobacterium in the milk is intermittent and less than $30 \%$ of the infected animals eliminate the Mycobacterium for this way (9).

Previous studies have been successful documenting the applicability of the PCR based in IS6110 as molecular method of detection of the members of the $M$. tuberculosis complex causative of tuberculosis in animals (10-12), especially for direct detection of $M$. bovis in tissues of bovine and milk where they have brought that provides rapid diagnosis of the disease.

On the other hand, in recent years, the develop of an alternative technology of molecular classification of the members of the complex M. tuberculosis called spoligotyping has been successfully applied in the investigations of molecular epidemiology of the tuberculosis, with special usefulness in bovine tuberculosis (13-16).

Considering the absence of true information and in order to document the current situation of the bovine tuberculosis in Colombia, that enables the adjustment of control measures in the frame of National Program of control and eradication of the bovine tuberculosis, we developed our first national investigation using the conventional and molecular tools.

\section{MATERIALS AND METHODS}

Study type. An observational analytical study was developed in cattle estates from eight Colombians departments, selected based in the results of tuberculin tests applied by the Colombian Agricultural Institute (ICA), within national epidemiological vigilance program for trace the $M$. bovis causing of bovine tuberculosis (17).
En Colombia, la prevalencia de tuberculosis bovina detectada post mortem es inexacta y el número de fincas oficialmente certificadas como libres de tuberculosis se ha incrementado en los últimos años (4). En el año 2014 Colombia produjo 6.717 millones de litros de leche y más de 837 millones de kilos de carne bovina (8), lo cual significó una alta proporción del ingreso de divisas para la nación, por lo tanto, un mejor conocimiento y documentación de la situación de tuberculosis bovina se hace necesario con el fin de adecuar y mejorar la vigilancia epidemiológica de esta patología garantizando el libre ingreso de los productos colombianos a los mercados mundiales (7).

En el campo del diagnóstico microbiológico de la tuberculosis bovina, el cual es demorado y costoso, se sabe que la excreción de Mycobacterium en la leche es intermitente y menos del 30\% de los animales infectados eliminan la micobacteria por esta vía (9).

Previos estudios han sido exitosos en documentar la aplicabilidad de la PCR basada en IS6110 como método molecular de detección de los miembros del complejo M. tuberculosis causantes de la tuberculosis en animales (10-12), especialmente para la detección directa de $M$. bovis en tejidos de bovinos y leche donde han reportado que proporciona un rápido diagnóstico de la enfermedad.

Por otra parte, en años recientes, se desarrolló una técnica alternativa de tipificación molecular de los miembros del complejo M. tuberculosis denominada spoligotyping que ha sido exitosamente aplicada en las investigaciones de epidemiologia molecular de la tuberculosis, con especial utilidad en tuberculosis bovina (13-16).

En vista de la ausencia de información y con el fin de documentar la situación actual de la tuberculosis bovina en Colombia para hacer posible la adecuación de las medidas de control en el marco del programa nacional de control y erradicación de la tuberculosis bovina, se planteó el desarrollo de la primera investigación a nivel nacional usando las herramientas convencionales y moleculares.

\section{MATERIALES Y MÉTODOS}

Tipo de estudio. Se realizó un estudio observacional analítico en fincas ganaderas de ocho departamentos de Colombia, seleccionadas con base en los resultados de las pruebas de tuberculina que aplica el Instituto Colombiano Agropecuario, (ICA), dentro del programa de vigilancia epidemiológica nacional, para la circulación de $M$. bovis causante de tuberculosis bovina (17). 
Samples included in the study. Samples of lymph node of head, thorax and abdomen, and woven from tubercular injuries of bovines and buffaloes sacrificed according to resolution of the ICA were taken. The animals not slaughtered from positives farms were undergoing to collection of nasal swab, blood or milk according to the criterion of ICA veterinarians. Also, were included in this study raw milk and fresh cheeses samples from municipalities where there were estates included in the study.

Specimen collection and transport. The samples were gathered during the years 2008 to 2010 , in cattle estates identified by ICA as positives to the tuberculin and in the plants of benefit, which were transported preserving the cold chain, to the Mycobacteria's Laboratory at the National Institute of Health (INS) in Bogota Colombia.

Processing of samples, lymph node and tissues with macroscopic lesions. 2 to $5 \mathrm{~g}$ of samples previously washed, were individually macerated into sterile mortars. $1 \mathrm{~g}$ of this macerated was placed into falcon plastic vial of $50 \mathrm{ml}$ with $9 \mathrm{ml}$ of acid oxalic $(4 \%)$ at $37^{\circ} \mathrm{C}$ during 20 minutes, after which we neutralized by $\mathrm{NaOH}$ $(4 \%)$ in the presence of red of phenol $(1 \%)$. It was centrifuged to $4000 \mathrm{xg}$ for 10 minutes at $4^{\circ} \mathrm{C}$. The supernatant was discarded and the sediment was washed by centrifugation twice and was resuspended with distilled sterile water (18-19).

Processing of milk samples. Aseptically were collected $50 \mathrm{ml}$ of milk, which were centrifuged for 30 minutes at $4.000 \mathrm{xg}$ and $4^{\circ} \mathrm{C} .21 \mathrm{ml}$ of the sediment was decontaminated with $3 \mathrm{ml}$ of lauryl sulfate of sodium, incubating at ambient temperature during 30 minutes. Later, this was centrifuged during 30 minutes at $4.000 \times \mathrm{xg}$ and $4^{\circ} \mathrm{C}$. The supernatant was discarded and the sediment was re-suspended with distilled sterile water (18-19).

Processing of nasal swabs samples. The samples of nasal swabs were dissolved by washing of hyssop, in $10 \mathrm{ml}$ of PBS. This product was centrifuged at $4.000 \mathrm{xg}$ during 30 minutes at $4^{\circ} \mathrm{C}$. The supernatant was discarded, preserving the sediment, which was decontaminated by Kudoh method (18-19).

Processing of blood samples. Samples of blood were subjected to centrifugation at 2.000 $x g$ during 10 minutes at $4^{\circ} \mathrm{C}$, to recover the white blood cells, which were lysates by adding 1 volume of sodium deoxycholate $(0.4 \%)$ incubating at ambient temperature 30 minutes. Later, were centrifuged at $4.000 x g$ during 30
Muestras incluidas en el estudio. Se tomaron muestras de ganglios linfáticos de cabeza, tórax y abdomen así como de tejidos con lesiones tuberculosas de bovinos y bufalinos sacrificados según resolución del ICA. A los animales no sacrificados de las fincas positivas se les tomó hisopado nasal, sangre o leche según criterio de los médicos veterinarios del ICA. También se incluyeron muestras de leche cruda y quesos frescos de municipios con fincas PPD positivas, incluidas en el estudio.

Toma de muestras y transporte. Las muestras fueron recolectadas durante los años 2008 a 2010, en fincas ganaderas identificadas por el ICA como positivas a la tuberculina y en las plantas de beneficio, las cuales fueron transportadas al laboratorio de Micobacterias del Instituto Nacional de Salud (INS) en Bogotá Colombia, conservando la cadena de frio.

Procesamiento de las muestras de ganglios linfáticos y tejidos con lesiones macroscópicas. De 2 a $5 \mathrm{~g}$ de muestra previamente lavada, fueron macerados individualmente en morteros estériles. $1 \mathrm{~g}$ del macerado se colocó en tubo falcón plástico de 50 $\mathrm{ml}$ con $9 \mathrm{ml}$ de ácido oxálico $(4 \%)$ a $37^{\circ} \mathrm{C}$ durante 20 minutos, después de lo cual se neutralizó con $\mathrm{NaOH}(4 \%)$ en presencia de rojo de fenol (1\%). Se centrifugó a $4000 x g$ por 10 minutos a $4^{\circ} \mathrm{C}$. El sobrenadante se descartó y el sedimento fue lavado 2 veces por centrifugación y se resuspendió en agua destilada estéril (18-19).

Procesamiento de las muestras de leche. $50 \mathrm{ml}$ de leche recogida en forma aséptica, fueron centrifugados a $4.000 \mathrm{xg}$ por 30 minutos a $4^{\circ} \mathrm{C}$. $21 \mathrm{ml}$ del sedimento se descontaminó con $3 \mathrm{ml}$ de lauril sulfato de sodio incubando a temperatura ambiente por 30 minutos. Posteriormente se centrifugó a $4.000 \times$ gor 30 minutos a $4^{\circ} \mathrm{C}$ y se descartó el sobrenadante el sedimento se resuspendió con agua destilada estéril (18-19).

Procesamiento de las muestras de hisopado nasal. Las muestras de hisopado nasal se disolvieron lavando el hisopo en $10 \mathrm{ml}$ de PBS. Posteriormente se centrifugó a $4.000 \mathrm{xg}$ por 30 minutos a $4^{\circ} \mathrm{C}$ y se descartó el sobrenadante, conservando el sedimento, que fue descontaminado por el método de Kudoh (18-19).

Procesamiento de las muestras de sangre. Las muestras de sangre se sometieron a centrifugación a $2.000 \times \mathrm{xg}$ por 30 minutos a $4^{\circ} \mathrm{C}$, para recuperar los glóbulos blancos, los cuales fueron lisados adicionando 1 volumen de deoxicolato de sodio $(0.4 \%)$ incubando a temperatura ambiente por 30 minutos. 
minutes and $4^{\circ} \mathrm{C}$. The supernatant was discarded and the sediment was re-suspended with $1 \mathrm{ml}$ distilled sterile water (18-19).

Bacilloscopy. The sediment obtained by processing of each one of the samples of lymph nodes, tissues with gross lesions, blood, swabs and milk, were extended on slide to realize bacilloscopy, staining with the Ziehl-Neelsen coloration to looking the presence of bacilli acid alcohol resistant (BAAR), by observation of 100 fields with a white light microscope(18-19).

Culture. The sediment obtained by processing of each one of the samples of lymph nodes and tissues with gross lesions, blood, swab or milk, was cultured by duplicate in culture middles: Lowenstein-Jensen and Stonebrink-Giraldo's modified (STG). The cultures were incubated at $37^{\circ} \mathrm{C}$ for growth readings, weekly up to completing 12 weeks when the negative cultures were discarded. The cultures with growth were submitted to Ziehl Neelsen coloration and those who presented BAAR were investigated by phenotypic tests of identification (18-19).

Phenotypic identification of species. The tests of species identification were carried out bearing in mind the recommendations from CDC of Atlanta. The cultures that presented growth were colored by Ziehl Neelsen to check the purity. So, those were processed by biochemical and enzymatic tests: niacin detection, nitrates reduction, catalase activity and semi quantitative catalase, tween hydrolysis, enzymatic activity of pyrazinamide and the acid phosphatase. In addition, we determined the inhibition of growth in LJ containing $\mathrm{NaCl}(5 \%)$; 2-tiofencarboxilic acid Hydrazide (TCH) and Hydroxylamine (HAS); in MacConkey agar, in Sauton and Sauton Picric (2\%) (18-19).

DNA Extraction. An aliquot of $1 \mathrm{~g}$ macerated or sediment obtained by processing of each one of samples of lymph nodes and tissues with gross lesions, blood, swab or milk, were submitted to extraction of DNA according to the recommendations of van Soolingen et al (20), method based in CTAB, chloroform-isoamyl alcohol, and precipitating with isopropanol. Every DNA sample obtained was re-suspended in a buffer TE $0.1 X$. The quantification of the DNA was realized in the gel of agarose to $0.8 \%(\mathrm{w} / \mathrm{v})$ by bromide of ethidium $0.5 \mathrm{ug} / \mathrm{mL}$ using DNA Ladder High MW Invitrogen (Cat No 10496-016) as reference pattern (20).

Genotypic Identification. An aliquot of macerated or sediment obtained by processing of each one of samples of lymph nodes and tissues
Posteriormente, se centrifugó a 4.000xg por 30 minutos a $4^{\circ} \mathrm{C}$. Se descartó el sobrenadante y el sedimento se resuspendió en $1 \mathrm{ml}$ de agua destilada estéril (18-19).

Baciloscopia. El sedimento obtenido del procesamiento de cada una de las muestras de ganglios linfáticos, tejidos con lesiones macroscópicas, sangre, hisopado y leche, fue extendido sobre lámina para realizar baciloscopia usando la tinción de Ziehl Neelsen buscando la presencia de bacilos ácido alcohol resistentes mediante observación de 100 campos con microscopio óptico de luz blanca (18-19).

Cultivo. El sedimento obtenido del procesamiento de cada una de las muestras de ganglios linfáticos y tejidos con lesiones macroscopicas, sangre, hisopado o leche, fue cultivado por duplicado en medio de cultivo Lowenstein-Jensen y Stonebrink modificado por Giraldo (STG). Los cultivos fueron incubados a $37^{\circ} \mathrm{C}$ con lecturas del crecimiento semanal hasta completar 12 semanas cuando los cultivos negativos fueron descartados. Los cultivos con crecimiento se sometieron a coloración de Ziehl Neelsen y los que presentaron BAAR fueron sometidos a pruebas de identificación fenotípica (18-19).

Identificación fenotípica de especie. Las pruebas de identificación de especie se llevaron a cabo teniendo en cuenta las recomendaciones del CDC de Atlanta. Los cultivos que presentaron crecimiento fueron coloreados con Ziehl Neelsen para verificar la pureza. Posteriormente se sometieron a las pruebas bioquímicas y enzimáticas tales como la detección de niacina, reducción de nitratos, actividad de catalasa y catalasa semicuantitativa en medio LJ, hidrólisis de tween, detección de la actividad enzimática de pirazinamidasa y de fosfatasa ácida. Además, se les realizó pruebas de inhibición del crecimiento en medio LJ conteniendo $\mathrm{NaCl}(5 \%)$, Hidracida del ácido 2-tiofencarboxilico ( $\mathrm{TCH})$, Hidroxilamina (HA) y en agar MacConkey, Sauton y Sauton Pícrico (2\%) (18-19).

Extracción de ADN. Una alícuota de $1 \mathrm{~g}$ del macerado o sedimento obtenido del procesamiento de las muestras de ganglios linfáticos y tejidos con lesiones macroscópicas, sangre, hisopado o leche, fue sometida a proceso de extracción de ADN según las recomendaciones de van Soolingen et al (20) basadas en el método de CTAB y cloroformo-alcohol isoamílico precipitando con isopropanol. Cada muestra de ADN obtenido fue resuspendida en buffer TE $0.1 X$. La cuantificación del DNA se realizó en gel de agarosa al $0.8 \%(\mathrm{p} / \mathrm{v})$ con bromuro de etidio $0.5 \mathrm{ug} /$ $\mathrm{mL}$, utilizando High DNA MW Ladder de Invitrogen (Cat No 10496-016) como patrón de referencia (20). 
with gross lesions, blood, swab or milk, were submitted to identification of Mycobacterium belonging to the $M$. tuberculosis complex by amplification PCR-IS6110. For the discrimination of the members of the complex, specifically the M. bovis, we used the molecular methodology of spoligotyping.

PCR-IS6110. The detection of the sequence of insertion IS6110, typical of M. tuberculosis complex, previous standardization, were developed through a PCR-IS6110 described by Kremer et al (21) in a mixture of reaction of the final volume of $50 \mu$ l that it contained $1.5 \mathrm{mM}$ of $\mathrm{MgCl} 2,0.125 \mathrm{mM}$ of dNTP's; $0.125 \mu \mathrm{M}$ of each primers INS1 (5'-CGTGAGGGCATCGAGGTGGC-3') and INS2 (5'-GCGTAGGCGTCGGTGACAAA-3') to amplified a 245 bp fragment of IS6110 insertion sequence. We used the C1000 Thermal Cycler Bio-Rad ${ }^{\circledR}$ to program of one initial cycle of denaturalization at $96^{\circ} \mathrm{C}, 5 \mathrm{~min}$ and 30 cycles of $96^{\circ} \mathrm{C} \times 1 \mathrm{~min}, 65^{\circ} \mathrm{C} \times 1 \mathrm{~min}$ and $72^{\circ} \mathrm{C} \times 1 \mathrm{~min}$ with a final extension of $72^{\circ} \mathrm{C} \times 7 \mathrm{~min}$. The amplification product was visualized in agarose gel $(1.5 \%)$ $(\mathrm{w} / \mathrm{v})$ with bromide of ethidium using molecular weight marker $50 \mathrm{pb}\left(\right.$ Sigma $\left.{ }^{\circledR}\right)$.

Spoligotyping. The discrimination of $M$ bovis from other members of $M$. tuberculosis complex, was realized using the molecular methodology of spoligotyping before described by Kamerbeer et al (22). From macerated or sediment obtained by processing of each one of samples of lymph nodes and tissues with gross lesions, blood, swab or milk and positive cultures a region of the locus DR amplifies with primers specifics $\mathrm{DRa}$ and $\mathrm{DRb}$ and the products of amplification hybridize in a membrane (Immunetics) in which oligonucleotides synthetic they have been covalently close. The detection is realized using streptavidin peroxidase brought together (Roche Diagnostics Ltd, UK) and the casing ECL (GE, Biotech). The results were translated from binary code to octal code for comparison.

Analysis of results. Several databases were created in spreadsheets Excel 2007 for every analysis types, one for each characterization of animals and microbiological results of studied animals by culture, ZN and molecular markers PCR-IS6110 and spoligotyping. The results of spoligotyping were comparison with the molecular patterns found in the International base SpolDB4 of the Institute Pasteur of the Guadeloupe (23), equally, comparison was made with the database of M bovis spoligotypes (24) to determine the SIT (spoligo international type), family and international location.
Identificación genotípica. Una alícuota del macerado o sedimento obtenido del procesamiento de las muestras de ganglios linfáticos y tejidos con lesiones macroscópicas, sangre, hisopado o leche, fue sometida a la amplificación por PCR-IS6110, para la identificación de micobacterias pertenecientes al complejo M. tuberculosis. Para la discriminación de los integrantes del complejo tuberculosis y específicamente el $M$. bovis, se realizó la metodología molecular de spoligotyping.

PCR-IS6110. La detección de la secuencia de inserción IS6110 típica del complejo $M$. tuberculosis, se realizó previa estandarización, a través de una PCR-IS6110 descrita por Kremer et al (21), en una mezcla de reacción con volumen final de $50 \mu \mathrm{l}$ que contenía $1.5 \mathrm{mM}$ de $\mathrm{MgCl}_{2}$, $0.125 \mathrm{mM}$ de dNTP's; $0.125 \mu \mathrm{M}$ de cada uno de los primer INS1 ( $5^{\prime}$ a $3^{\prime}$ CGTGAGGGCATCGAGGTGGC) e INS2 ( $5^{\prime}$ a $3^{\prime}$ GCGTAGGCGTCGGTGACAAA) para amplificar un fragmento de $245 \mathrm{pb}$ de la secuencia de inserción IS6110. La reacción se realizó en un C1000 Thermal Cycler Biorad $\AA$ usando 1 ciclo de desnaturalización inicial de $96^{\circ} \mathrm{C}$ de $5 \mathrm{~min}, 30$ ciclos de $96^{\circ} \mathrm{C} \times 1 \mathrm{~min}$, $65^{\circ} \mathrm{C} \times 1$ min y $72^{\circ} \mathrm{C} \times 1$ min con una extensión final de $72^{\circ} \mathrm{C} \times 7 \mathrm{~min}$. El producto de amplificación se visualizó en gel de agarosa al $1.5 \%(p / v)$ con bromuro de etidio utilizando marcador de talla molecular de $50 \mathrm{pb}\left(\right.$ Sigma $\left.^{\circledR}\right)$.

Spoligotyping. La discriminación del $M$. bovis y demás miembros del complejo, se realizó utilizando la metodología molecular de spoligotyping previamente descrita por Kamerbeer et al (22), a partir del macerado o sedimento obtenido del procesamiento de las muestras de ganglios linfáticos y tejidos con lesiones macroscópicas, sangre, hisopado o leche y a partir de cultivos positivos. Una región del locus DR se amplificó con primers específicos DRa y DRb y los productos de amplificación se hibridaron en una membrana (Immunetics) en la cual oligonucleótidos sintéticos habían sido covalentemente unidos, la detección se realizó utilizando streptavidina peroxidasa conjugada (Roche Diagnostics Ltd, UK) y el estuche ECL (GE,Biotech). Los resultados fueron traducidos a código binario y código octal para la comparación.

Análisis de resultados. Se generaron varias bases de datos en hojas de cálculo Excel 2007 para cada tipo de análisis, cada una para la caracterización de los animales y los resultados microbiológicos mediante cultivo, ZN y marcadores moleculares PCR-IS6110 y spoligotyping. Los resultados de spoligotyping fueron comparados con los patrones moleculares encontrados en la base Internacional SpolDB4 del Instituto Pasteur de la Guadalupe (23), 
Descriptive analysis. Descriptive analysis was realized of the animals characteristics studied according to the department and municipality of origin.

Independence analysis. To identify the relation between the animals' variables as species, sex and race with the Mycobacterium infection was used independence tests at 0.05 significance level, If the awaited counts are superior to 5, the probability corresponds to a distribution of chi- square. If the counts are low, the probability corresponds to Fisher's exact test (25).

Ethics statement. The Ethic Committee from National Institute of Health endorsed the study, considering that was an investigation without risk. The blood, tissues and nasal swabs samples from the cattle used for culture and/or DNA extraction, were collected under the directive of the Colombian Agricultural Institute, (ICA) within national epidemiological vigilance program (17) and their use in the present study for other purposes as to trace the $M$. bovis causing of bovine tuberculosis were not routine.

\section{RESULTS}

Origin of samples. 492 samples were studied in total. $86.6 \%$ was from bovine and $13.4 \%$ from buffaloes. The bovine ones of those who took the samples were of race Holstein (39.2\%) and Zebu $(22.1 \%)$, whereas the buffaloes were principally from race Murra (26\%). To both species, the samples they belonged principally from females: $81.5 \%$ in bovines and $56.1 \%$ in buffaloes.
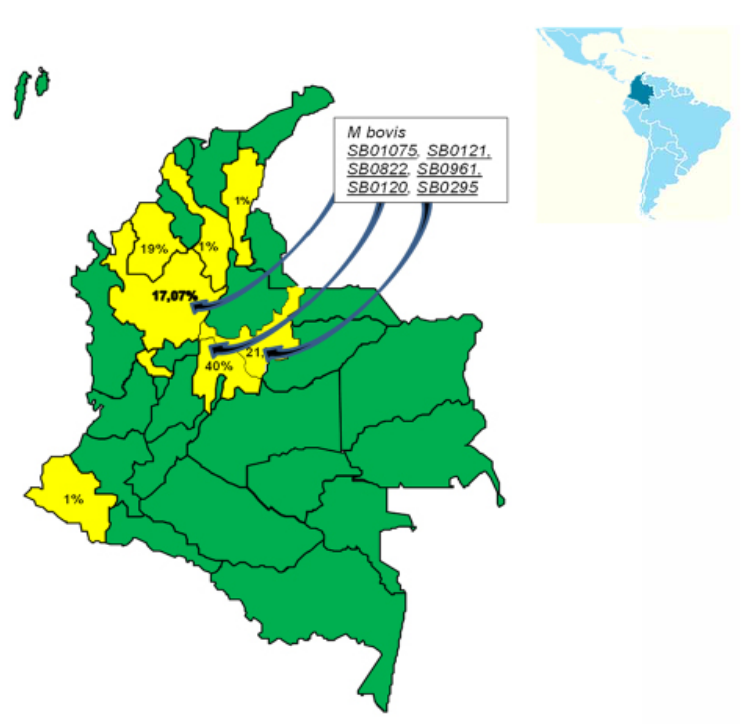

Figure 1. Departments of origin of the samples included in the study and the $M$ bovis isolated. igualmente se realizó comparación con la base de datos de M. bovis spoligotype Database (24) para determinar su SIT (spoligo internacional type), familia y ubicación internacional.

Análisis descriptivo. Se realizó análisis descriptivo de las características de los animales estudiados teniendo en cuenta departamento y municipio de origen.

Análisis de independencia. Para identificar la relación entre las variables de los animales como: especie, sexo y raza con la infección por Mycobacterium, se utilizaron pruebas de independencia con un nivel de significancia de 0.05; si los recuentos esperados eran superiores a cinco, la probabilidad correspondía a una distribución de Chi cuadrado, si los recuentos eran bajos se realizó una prueba de Fisher exact (25).

Aspectos Éticos: El Comité de Ética del Instituto Nacional de Salud avaló la investigación, teniendo en cuenta que se consideró como una investigación sin riesgo. Las muestras de sangre, leche, tejidos e hisopos nasales de los bovinos, utilizadas para los cultivos y extracción de ADN se recolectaron bajo las directrices del Instituto Colombiano Agropecuario (ICA), dentro del Programa de Vigilancia Epidemiológica Nacional de la tuberculosis bovina (17) y su uso en el presente estudio para otros propósitos como el rastreo de $M$. bovis causante de tuberculosis bovina no era rutinario.

\section{RESULTADOS}

Procedencia de las muestras. En total se estudiaron 492 muestras; tomadas de bovinos (86.6\%) y tomadas de bufalinos (13.4\%). Las razas de los bovinos fueron, Holstein (39.2\%) y Cebú $(22.1 \%)$, mientras que la raza de los bufalinos fue principalmente la Murra (26\%). En ambas especie las muestras provinieron principalmente de hembras: $81.5 \%$ en bovinos y $56.1 \%$ en bufalinos, de los departamentos de Cundinamarca $n=197$ (40\%) seguido de Boyacá $n=107$ (21.74\%), Magdalena $\mathrm{n}=94(19.10 \%)$ y Antioquia $\mathrm{n}=84(17.07 \%)$; los demás departamentos aportaron menor proporción de muestras (Figura 1).

Tipo de muestras estudiadas. En la tabla 1 se observa el tipo de muestras estudiadas según el tipo de bovino y el departamento de procedencia.

\section{Resultados de la investigación microbiológica} Coloración de Zielh Neelsen. Se obtuvo 7.11\% $(n=35)$ de positividad que mostró una concordancia del $85.71 \%$ con respecto a los resultados del cultivo. La totalidad de las muestras que fueron positivas 
The samples were from Cundinamarca's department $n=197(40 \%)$, followed by Boyacá $\mathrm{n}=107(21.74 \%)$, Magdalena $\mathrm{n}=94(19.10 \%)$ and Antioquia $\mathrm{n}=84(17.07 \%)$; other departments contributed with minor proportion of samples. (Figure1).

Type of samples studied. In the table 1 we discriminate the type of sample studied according to class of cattle and department of origin.

\section{Microbiological Investigation.}

Zielh Neelsen coloration. Were obtained $7.11 \%(n=35)$ positive samples that showed a concordance of $85.71 \%$ with regard to the culture results. The totality of positive samples by this procedure, were samples of ganglions, $54.28 \%$ from bovine and $45.71 \%$ from buffaloes.

Culture Investigation. In 492 studied samples we found $23.98 \%(n=118)$ positive samples to culture, of which $18.64 \%(n=22)$ were of nasal swabs, $1.69 \%$ $(n=2)$ of milk and $79.66 \%(n=94)$ of lymphatic ganglions. In turn, $73.73 \%$ of these samples were from bovines and $26.27 \%$ from buffaloes.

The phenotypic identification of the positive cultures showed M. bovis in $71.19 \%(n=86)$ of them and $14.4 \%(n=17)$ M. tuberculosis complex, whereas $7.62 \%(n=9)$ corresponded to M. tuberculosis and $5.08 \%(n=6)$ to Mycobacterium spp.

it's interesting to highlight that all isolations of $M$. bovis were achieved from lymphatic ganglions samples, whereas the $M$. tuberculosis and the M. $s p$ were obtained principally of nasal swabs $(n=22)$ and in minor proportion from ganglions $(n=8)$ and from milk $(n=2)$.

The isolations achieved by this culture methodology coming only from Antioquia, Cundinamarca, Boyacá and Magdalena departments, also specifically from seven municipalities: Chibolo, Chiquinquirá, Puerto Nare, Santa Rosa de Osos, Simijaca, Tarazá y Yondó. In total 10 estates had positive cultures to Mycobacterium (Table 2). por este procedimiento eran muestras de ganglios linfáticos provenientes en el $54.28 \%$ de bovinos y el $45.71 \%$ de bufalinos.

Investigación por cultivo. En las 492 muestras estudiadas se encontró $23.98 \%(n=118)$ de positividad al cultivo, de las cuales $18.64 \%(n=22)$ eran muestras de hisopado nasal, $1.69 \%(n=2)$ de leches y $79.66 \%$ $(n=94)$ de ganglios linfáticos. Al mismo tiempo el $73.73 \%$ de estas muestras provenían de bovinos y $26.27 \%$ de bufalinos.

La identificación fenotípica de los cultivos positivos mostró M. bovis en el $71.19 \%(n=86)$ de ellos y $14.4 \%$ $(n=17)$ de $M$. tuberculosis complex, mientras que el $7.62 \%(n=9)$ correspondieron a M. tuberculosis y $5.08 \%(n=6)$ correspondieron a Mycobacterium spp.

Es interesante resaltar que todos los aislamientos de $M$. bovis se lograron a partir de muestras de ganglios linfáticos, mientras que el M. tuberculosis y el M. spp se obtuvieron principalmente de hisopados nasales $(n=22)$ y en menor proporción de ganglios linfáticos $(n=8)$ y de leches $(n=2)$.

Los aislamientos logrados por esta metodología de cultivo provenían únicamente de los departamentos de Antioquia, Cundinamarca, Boyacá y Magdalena, también específicamente de siete municipios: Chibolo, Chiquinquirá, Puerto Nare, Santa Rosa de Osos, Simijaca, Tarazá y Yondó. En total 10 fincas tuvieron cultivos positivos para Mycobacterium (Tabla 2).

\section{Investigación molecular}

Resultados de PCR-IS6110. La metodología molecular de amplificación en cadena de la polimerasa usando como blanco molecular la secuencia de inserción IS6110 que es especifica del complejo tuberculosis, presentó una positividad del $51.02 \%$ $(n=251)$ por lo cual fue dos veces más sensible que el cultivo y siete veces más sensible que la coloración de ZN.

Resultados de spoligotyping. $47.56 \%(n=234)$ muestras fueron positivas por esta metodología,

Table 1. Samples enrolled in this study, discriminated by type and from origin department.

\begin{tabular}{|c|c|c|c|c|c|c|c|}
\hline Department & Specie & Ganglions/tissues & Nasal swabs & Blood & Raw Milk & Fresh Cheese & Total \\
\hline \multirow{2}{*}{ Antioquia } & Buffaloes & 66 & 0 & 0 & 0 & 0 & 66 \\
\hline & Bovine & 18 & 0 & 0 & 0 & 0 & 18 \\
\hline Boyacá & Bovine & 87 & 0 & 0 & 20 & 20 & 107 \\
\hline Cesar & Bovine & 2 & 0 & 0 & 0 & 0 & 2 \\
\hline Córdoba & Bovine & 1 & 0 & 0 & 0 & 0 & 1 \\
\hline Cundinamarca & Bovine & 64 & 83 & 38 & 2 & 2 & 197 \\
\hline Magdalena & Bovine & 0 & 90 & 0 & 0 & 0 & 94 \\
\hline Nariño & Bovine & 0 & 0 & 0 & 3 & 3 & 3 \\
\hline Risaralda & Bovine & 0 & 0 & 0 & 4 & 4 & 4 \\
\hline Total & & 238 & 173 & 38 & 14 & 29 & 492 \\
\hline
\end{tabular}


Table 2. Microbiological and molecular results from samples studied by year and department.

\begin{tabular}{|c|c|c|c|c|c|c|c|c|}
\hline \multirow[b]{2}{*}{ year } & \multicolumn{4}{|c|}{ SAMPLE } & \multicolumn{4}{|c|}{ POSITIVE RESULTS } \\
\hline & $\mathbf{N}^{\circ}$ & $\begin{array}{l}\text { Animal } \\
\text { specie }\end{array}$ & Origen & $\begin{array}{l}\text { Depto/ } \\
\text { municip }\end{array}$ & $\mathbf{Z - N}$ & CULTURE & $\begin{array}{c}\text { PCR- } \\
\text { IS6110 }\end{array}$ & $\begin{array}{c}\text { Specie } \\
\text { (spoligotyping) }\end{array}$ \\
\hline 2008 & 19 & $\begin{array}{c}6 \text { bovineos } \\
13 \text { buffaloes }\end{array}$ & Ganglions & $\begin{array}{c}\text { Choco, } \\
\text { Antioquia }\end{array}$ & 0 & 0 & 1 & 1 M.tb comp NR \\
\hline 2008 & 9 & bovines & Ganglions & $\begin{array}{l}\text { Antioquia: } \\
\text { Santa Rosa }\end{array}$ & 9 & 9 & 9 & 9 M. bovis SB01075 \\
\hline 2008 & 7 & buffaloes & Ganglions & $\begin{array}{l}\text { Antioquia: } \\
\text { Cáceres }\end{array}$ & 0 & 0 & 0 & \\
\hline 2008 & 17 & buffaloes & Ganglions & $\begin{array}{l}\text { Antioquia: } \\
\text { Yondó }\end{array}$ & 8 & 12 & 12 & $\frac{8 \text { M. bovis SB0822 }}{\frac{3 \text { M. bovis SB0121 }}{1 \text { M.tb comp NR }}}$ \\
\hline 2009 & 2 & bovines & Ganglions & $\begin{array}{l}\text { Córdoba, } \\
\text { Antioquia }\end{array}$ & 0 & 0 & 0 & \\
\hline 2009 & 6 & bovines & Ganglions & $\begin{array}{c}\text { Cundinamarca: } \\
\text { Nemocón }\end{array}$ & 0 & 0 & 2 & $\begin{array}{c}1 \text { M.tb comp NR } \\
1 \text { MANU-2(54) }\end{array}$ \\
\hline 2009 & 2 & bovines & Ganglions & Antioquia & 0 & 0 & 0 & \\
\hline 2009 & 2 & bovines & Ganglions & $\begin{array}{c}\text { Cesar: } \\
\text { Bosconia }\end{array}$ & 0 & 0 & 0 & \\
\hline 2009 & 58 & bovines & Ganglions & $\begin{array}{c}\text { Cundinamarca: } \\
\text { Simijaca }\end{array}$ & 2 & 5 & 12 & $\begin{array}{c}3 \text { M. bovis SB01075 } \\
2 \text { M.tb comp NR } \\
1 \text { Mtb U(523) } \\
6 N D\end{array}$ \\
\hline 2009 & 83 & bovines & Hisopado nasal & $\begin{array}{c}\text { Cundinamarca: } \\
\text { Simijaca }\end{array}$ & 0 & 2 & 43 & $\begin{array}{c}5 \text { Mtb U(523) } \\
4 \text { Mtb U(1146) } \\
4 \text { M.tb comp NR } \\
4 \text { MANU-2(54) } \\
25 \text { Mtb T1(53) } \\
1 \text { ND }\end{array}$ \\
\hline 2009 & 10 & bovines & Leche cruda & $\begin{array}{c}\text { Cundinamarca: } \\
\text { Simijaca }\end{array}$ & 0 & 0 & 2 & 2 M.tb comp NR \\
\hline 2009 & 90 & bovines & Nasal swabs & $\begin{array}{l}\text { Magdalena: } \\
\text { Chibolo }\end{array}$ & 0 & 20 & 74 & $\begin{array}{c}4 \text { M.tb comp NR } \\
54 \text { MANU-2(54) } \\
12 \text { Mtb U(523) } \\
1 \text { Mtb U(1146) } \\
2 \text { Mtb T1(53) } \\
1 N D\end{array}$ \\
\hline 2009 & 4 & bovines & Raw Milk & $\begin{array}{l}\text { Magdalena: } \\
\text { Chibolo }\end{array}$ & 0 & 2 & 2 & $\begin{array}{c}1 M t b U(523) \\
1 N D\end{array}$ \\
\hline 2009 & 29 & buffaloes & Ganglions & $\begin{array}{c}\text { Antioquia: } \\
\text { Puerto Nare, Taraza }\end{array}$ & 8 & 19 & 24 & $\begin{array}{c}\frac{9 M . \text { bovis } S B 0121}{4 M . \text { bovis } S B 0822} \\
\frac{2 M . \text { bovis } S B 0961}{2 M . \text { bovis } S B 0120} \\
\frac{1 M . \text { bovis } S B 0295}{2 M . ~ t b \text { comp NR }} \\
4 N D\end{array}$ \\
\hline 2010 & 87 & bovines & Ganglions & $\begin{array}{c}\text { Boyacá: } \\
\text { Chiquinquirá }\end{array}$ & 8 & 49 & 60 & $\begin{array}{c}44 \mathrm{M} . \text { bovis SB01075 } \\
6 \text { M. tb comp NR } \\
2 M A N U-2(54) \\
8 N D\end{array}$ \\
\hline 2010 & 38 & bovines & Blood & $\begin{array}{c}\text { Cundinamarca: } \\
\text { Simijaca }\end{array}$ & 0 & 0 & 12 & $\begin{array}{c}5 \text { M. tb comp NR } \\
3 M A N U-2(54) \\
2 M A N U-2(1190) \\
2 N D\end{array}$ \\
\hline 2010 & 29 & bovines & Fresh Cheese & $\begin{array}{c}\text { Boyacá, } \\
\text { Cundinamarca, } \\
\text { Nariño: Pasto, } \\
\text { Risaralda }\end{array}$ & 0 & 0 & 4 & 4 M. tb comp NR \\
\hline & 492 & & & & 35 & 118 & 257 & \\
\hline
\end{tabular}




\section{Molecular investigation}

Results of PCR-IS6110. The molecular methodology of amplification by polymerase chain reaction using as molecular target the insertion sequence IS6110 that is specific of the Mycobacterium tuberculosis complex, It present a positivity of $51.02 \%(n=251)$ for which it was two times more sensitively that the culture and seven times more sensitive that ZN's coloration.

Results of spoligotyping. $47.56 \%(n=234)$ of samples showed positivity for this methodology with a pattern belonging to $M$ bovis in the $34.13 \%(n=86)$ and $65.87 \%(n=148)$ with a pattern from $M$ tuberculosis. We identified 36 different genotypes and there were 22 samples that did not present pattern since did not achieve hybridization, although they amplified (Figure 2).

Among the isolations with pattern from M. bovis family, 7 were spoligotypes before reported: SB1075 (56 isolations), SB0822 (12 isolations), SB0961 (2 isolations), SB0121 (12 isolations), SB0295 (1 isolations) SB1190 (1 isolation) and 1 spoligotype SB0120 (2 isolations). Therefore, the great majority of samples that presented pattern from the $M$. bovis family already had reported in the database of $M$. bovis Spoligotype (24).

Among the samples with spoligotypes not belonging to $M$. bovis family, we found six families where the majority was constituted by MANU 2 SIT $54(n=64)$, followed by the genotype of $M$. tuberculosis NR $(n=31)$ not reported, and for the genotype T1 SIT $53(n=27)$. Also, there were present the genotypes U SIT 523; U SIT 1146 and MANU 2 SIT 1190 with 19, 5 and 2 isolates respectively (Figure 3 ).

Like the results show, from the culture methodology we can observed that the nasal swabs $(n=115)$ were the main contributors of genotypes, different from M. bovis family, though also some ones came from ganglions $(n=16)$ milk $(n=3)$, blood $(n=10)$ and cheeses $(n=4)$.

\footnotetext{
Relation between variables of the herd and the presence of Mycobacterium tuberculosis complex in the animals. In the evaluation of possible factors related to the presence of Mycobacterium belonging to the Mycobacterium tuberculosis complex in animals (according to the test of PCR-IS6110), met significant association for $79.8 \%$ of positivity versus $20.21 \%$ healthy animals from Magdalena's department $(p<0.0001)$. In contrast, Cundinamarca show minor risk of having Mycobacterium ( $p<0.0001$, Table 3).
}

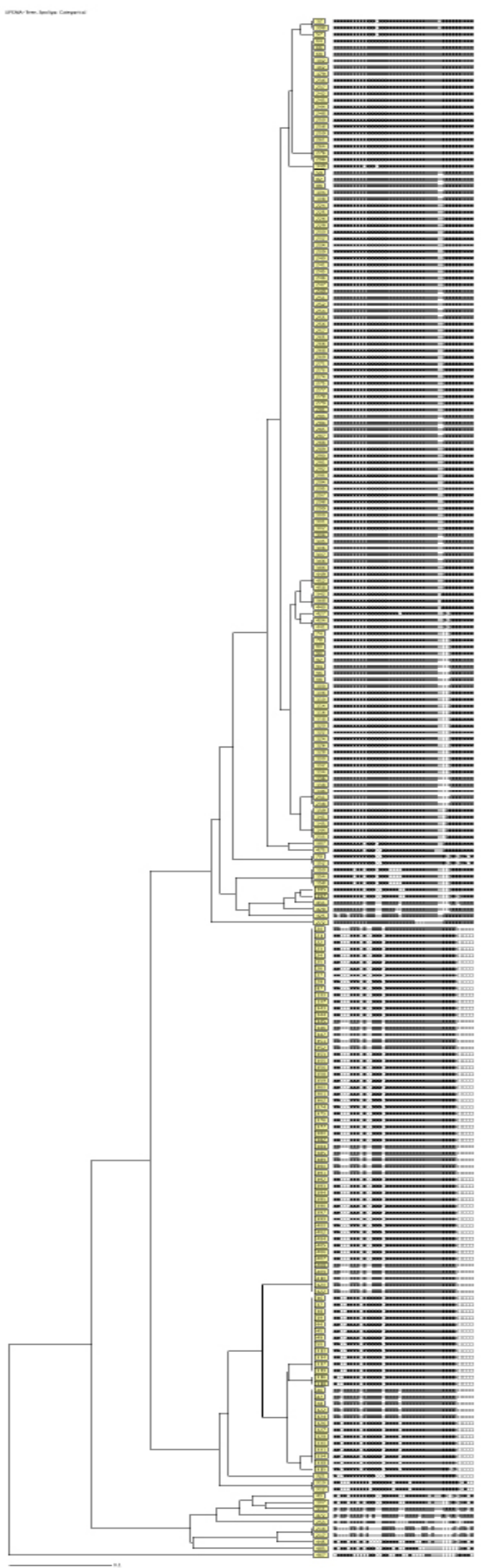

Figure 2. Dendogram of relation from spoligotypes of $M$. tuberculosis complex identified in the study. 
Mycobacterium tuberculosis complex

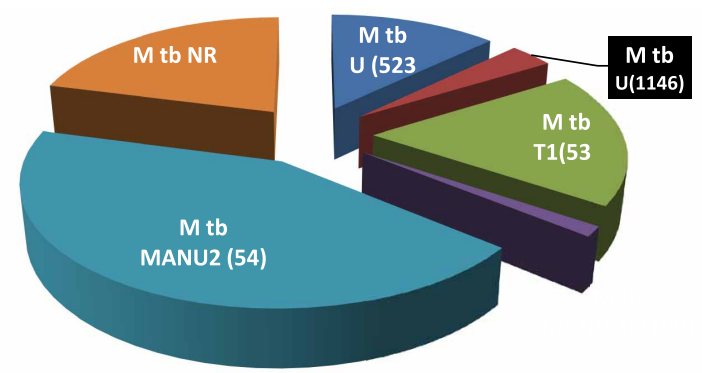

Figure 3. Distribution of M. tuberculosis genotypes not belonging to $M$ bovis family identified in the study.

Tabla 3. Resultados de las pruebas de Chi-cuadrado entre la presencia de Mycobacterium, las características del animal y procedencia.

\begin{tabular}{|c|c|c|c|c|c|c|}
\hline \multirow{2}{*}{\multicolumn{2}{|c|}{ Factors }} & \multirow{2}{*}{$\begin{array}{c}\text { PR > } \\
\text { Tables* }\end{array}$} & \multicolumn{2}{|c|}{ Positiveo } & \multicolumn{2}{|c|}{ Negative } \\
\hline & & & Real & Expected & Real & Expected \\
\hline \multicolumn{2}{|l|}{ Antioquia } & 0.8273 & $51 \%$ & $50 \%$ & $49 \%$ & $50 \%$ \\
\hline \multicolumn{2}{|l|}{ Boyacá } & 0.1003 & $58 \%$ & $50 \%$ & $42 \%$ & $50 \%$ \\
\hline \multicolumn{2}{|l|}{ Cesar } & - & - & $50 \%$ & $100 \%$ & $50 \%$ \\
\hline \multicolumn{2}{|l|}{ Córdoba } & - & - & $50 \%$ & $100 \%$ & $50 \%$ \\
\hline \multicolumn{2}{|c|}{ Cundinamarca } & $<0.0001$ & $36 \%$ & $50 \%$ & $64 \%$ & $50 \%$ \\
\hline \multicolumn{2}{|c|}{ Magdalena } & $<0.0001$ & $80 \%$ & $50 \%$ & $20 \%$ & $50 \%$ \\
\hline \multicolumn{2}{|l|}{ Nariño } & 0.5637 & $33 \%$ & $50 \%$ & $67 \%$ & $50 \%$ \\
\hline \multicolumn{2}{|l|}{ Risaralda } & - & - & $50 \%$ & $100 \%$ & $50 \%$ \\
\hline \multirow{2}{*}{ Specie } & Buffaloes & (200 & $7 \%$ & $7 \%$ & $7 \%$ & $7 \%$ \\
\hline & Bovine & 0.9300 & $44 \%$ & $44 \%$ & $42 \%$ & $42 \%$ \\
\hline \multirow{2}{*}{ Buffalo } & Female & 0.2084 & $40 \%$ & $43 \%$ & $30 \%$ & $26 \%$ \\
\hline & Male & & $23 \%$ & $19 \%$ & $8 \%$ & $11 \%$ \\
\hline \multirow{2}{*}{ Bovine } & Female & & $56 \%$ & $56 \%$ & $42 \%$ & $42 \%$ \\
\hline & Male & 0.4001 & $1 \%$ & $1 \%$ & $1 \%$ & $1 \%$ \\
\hline \multirow{2}{*}{ Bovine } & Holstein & ค & $26 \%$ & $35 \%$ & $38 \%$ & $29 \%$ \\
\hline & Cebú & $<0.0001$ & $29 \%$ & $20 \%$ & $7 \%$ & $16 \%$ \\
\hline
\end{tabular}

To other risk factors such as: species, sex within species, or race for cattle (buffaloes only report to one species), were found in Holstein, was found that have a negative percentage above than expected exhibiting a lesser presence of mycobacteria which should randomly. Contrary, in Zebu having values above those expected for animal reports with mycobacterial infection (Table 3 ).

\section{DISCUSSION}

By the present research, it was possible to demonstrate for the first time that in Colombia exist at least 7 genotypes of $M$. bovis, which are identificando un patrón perteneciente a $M$. bovis en el $34.13 \%(n=86)$ de ellas y $65.87 \% \quad(n=148)$ presentaron un patrón perteneciente a $M$. tuberculosis. Se identificaron 36 genotipos diferentes y hubo 22 muestras que no presentaron patrón debido a que no lograron hibridar aunque amplificaron (Figura 2).

Entre los aislamientos con patrón de familias M. bovis, se encontraron 7 spoligotypes reportado previamente: SB1075 (56 aislamientos), SB0822 (12 aislamientos), SB0961 (2 aislamientos), SB0121 (12 aislamientos), SB0295 (1 aislamiento) SB 1190 (1 aislamiento) y SB0120 (2 aislamientos). Por lo tanto, la gran mayoría de muestras que presentaron patrón de esta familia, M. bovis, ya se habían reportado en la base de datos de M. bovis spoligotype Database (24).

Entre las muestras con spoligotypes de patrón no perteneciente a la familia $M$. bovis se encontraron seis familias donde la familia mayoritaria estuvo constituida por el genotipo MANU 2 SIT $54(n=64)$, seguido por el genotipo de M. tuberculosis NR $(n=31)$ no reportado y por el genotipo T1 SIT $53(n=27)$. También estaban presentes los genotipos U SIT 523; U SIT 1146 y MANU 2 SIT 1190 con 19, 5 y 2 muestras respectivamente (Figura 3 ).

Igual que lo visto en los resultados de la metodología de cultivo, se observó que los hisopados nasales $(n=115)$ son los que aportan los genotipos de familias diferentes al M. bovis; aunque también se encontraron en las nuestras de ganglios linfáticos $(n=16)$ en leches $(n=3)$, en sangre $(n=10)$ y en quesos $(n=4)$.

Relación entre variables del hato y la presencia de micobacterias del complejo M. tuberculosis en los animales. En la evaluación de posibles factores relacionados con la presencia de micobacterias del complejo M. tuberculosis en los animales (según la prueba de PCR-IS6110), se encontró asociación significativa para animales provenientes del departamento de Magdalena $(p<0.0001)$ con $79.8 \%$ de positividad versus $20.21 \%$ sanos. Contrariamente, Cundinamarca mostró menor riesgo de tener micobacterias $(p<0.0001$, Tabla 3). Al relacionar los otros factores de riesgo como la especie, el sexo dentro de cada especie, o la raza para los bovinos (para búfalos sólo se reporta una especie), se encontró que los Holstein tienen un porcentaje de negativos por encima de lo esperado, es decir, muestran una menor presencia de micobacterias que las que se debería al azar. Contrario a la Cebú que presenta valores por encima de los esperados para los reportes de animales con micobacterias (Tabla 3).

\section{DISCUSIÓN}

Mediante esta investigación se pudo evidenciar por primera vez que en Colombia existen al menos 7 genotipos de $M$. bovis que se encuentran infectando $y$ 
infecting and sicken to bovines and buffaloes from four different Colombian's departments. This is constituted in a serious threat of zoonosis not only for the manipulators of the estates infected, but also for the manipulators of the productive chain and the final consumers. This finding highlights the recommendation to strengthen surveillance for compliance with Decree 1880 of 2011 on guidelines for the marketing of raw milk for human consumption (26).

The genotype SB1075 that was the majoritary found in our study has been reported infecting cattle from United Kingdom and has been confirmed that is slightly frequent in the world's statistics. Similar situation happens with the other 2 frequent genotypes in this study: the SB0822 and the SB0121 previously reported in Holland, Spain and Latin America (Brazil and Mexico)(27).

Therefore, it is extremely beneficial correlate the findings of present study with the very low infections incidence, historically observed and demonstrated by PPD and by microbiological investigation into Latin american human population (28), with the reported in colombian population where a single case caused by $M$. bovis, was confirmed in the INS in 2012 suggesting low infectivity/virulence of $M$. bovis circulating in Colombia, specifically from the mentioned departments.

Since by means of the statistical analysis it was possible to demonstrate that the high presence of M. bovis and not bovis was statistically significant in Magdalena's department, it is there where principally there must be intensified the measures of vigilance and control in farms and products by the ICA.

Another powerful finding, it constitutes to have demonstrated that exists a considerable proportion of animals and samples carrying M. tuberculosis of different genotypes between which there stands out the MANU 2 and the T1, that are consider ancestors of the M. tuberculosis complex, which have a minor virulence for the bovine/buffalo, as for human being. Though possibly they are responsible for the positive tuberculin results in the herds, neither produce disease in the cattle and they do not even affect them in the magnitude that it does the $M$. bovis that is really pathogenic for the cattle and they could be competing for the host, displacing the $M$. bovis in ranching (29).

In this regard, there exist studies that demonstrate that the M. tuberculosis find in the ranching it's a reflection of the situation of tuberculosis in human beings in such regions (30-32). This finding puts enfermando a bovinos y bufalinos de cuatro diferentes departamentos del país, lo cual constituye una seria amenaza para la salud pública por la posibilidad de zoonosis no sólo a los manipuladores de las fincas infectadas sino también para los manipuladores de la cadena productiva y los consumidores finales. Este hallazgo también genera la recomendación de fortalecer la vigilancia para el cumplimiento del decreto 1880 de 2011 sobre los lineamientos de la comercialización de leche cruda para el consumo humano (26).

El genotipo SB1075 que fue el más frecuente encontrado en nuestro estudio, ha sido reportado infectando ganado del Reino Unido y se ha confirmado que es poco frecuente en las estadísticas mundiales; similar situación sucede con los otros dos genotipos frecuentes en el presente estudio: el SB0822 y el SB0121 reportados previamente en Holanda, España y en Latinoamérica en Brasil y México. (27)

Por lo anterior, es muy importante correlacionar los hallazgos del presente estudio, con la baja incidencia de infección, demostrada por PPD y por investigación microbiológica, a nivel poblacional en humanos de Latinoamérica (28), y a lo históricamente evidenciado en Colombia, donde un único caso de tuberculosis causado por M. bovis fue confirmado en el INS en el año 2012 lo cual sugiere una baja infectividad/ virulencia del $M$. bovis circulante en Colombia, específicamente en los departamentos mencionados.

Debido a que mediante el análisis estadístico se pudo evidenciar que la mayor presencia de Mycobacterium bovis y no bovis fue estadísticamente significativa en las fincas de Magdalena, es allí donde principalmente se deben intensificar las medidas de vigilancia y control de los predios y productos por parte del ICA.

Un hallazgo bien importante lo constituye el haber demostrado que existe una considerable proporción de muestras de animales portadores de M. tuberculosis de diferentes genotipos entre los que sobresale el MANU 2 y el T1 que se consideran ancestros del complejo $M$. tuberculosis, que tienen una menor virulencia para el bovino/bufalino al igual que para el humano y que aunque posiblemente estos sean responsables de los resultados de tuberculina positiva en los hatos, no producen enfermedad en el ganado ni los afectan en la magnitud que lo hace el $M$. bovis que si es patógeno para el ganado y pudieran estar compitiendo por el hospedero, desplazando al M. bovis de las ganaderías. (29)

A este respecto, existen estudios que demuestran que el encontrar $M$. tuberculosis en las ganaderías, es un reflejo de la situación de la tuberculosis en humanos en tales regiones (30-32) lo cual pone en evidencia la necesidad de realizar mayores esfuerzos para el control de la tuberculosis en humanos en Colombia. 
of present the significant efforts that are needed for the control of tuberculosis in human beings in Colombia.

Nevertheless, the true role of this $M$. tuberculosis, found in the studied animals, must be investigated at depth since this one can be the source responsible for the maintenance of the human tuberculosis in endemic form in our country. It is necessary to highlight the fact that it becomes necessary to complement this investigation with the study of other animals that they find in the estates so positives as negative, to demonstrate the presence of animals carrying Mycobacterium in subclinical state that they can be the reservoirs of this Mycobacterium.

The results of this investigation constitute topics of interest to Public Health \& Social Protection's responsible from Colombia, since it is their competition and responsibility developed the control of tuberculosis human as well as the prevention of the zoonosis.

In short and according to our findings, it is advisable to restore the program of epidemiological vigilance of the bovine tuberculosis using the methodologies proved in the present study, initially in the departments where we found positivity to $M$. bovis and/or M. tuberculosis.

Secondly one recommends realizing studies more deep with relation to the presence of Mycobacterium tuberculosis complex, different from the $M$. bovis as they are the MANU 2 and the T1 genotypes both in the wild environment as in the manipulators of the bovine production chain.

This study confirmed the circulation in Antioquia, Boyacá, Cundinamarca and Magdalena departments of at least 7 genotypes of Mycobacterium bovis, causing bovine tuberculosis in cattle from ranches. This information is useful for programs surveillance in public health and animal health addressed to articulation of joint actions to build regulatory frameworks for the elimination and control of zoonoses, all of which contribute to improve competitiveness in the chain cattle production, and will impact the fulfillment of international animal health standards to increase access to world markets, improving the economy and directly benefiting to public health.

\section{Acknowledgements}

All personnel working in the National Program for Prevention and Control of Bovine Tuberculosis and Brucellosis ICA in Colombia, for its accompaniment to the sampling areas.
No obstante, el verdadero papel del $M$. tuberculosis encontrado en los animales estudiados, debe ser investigado a profundidad puesto que este puede ser la fuente responsable del mantenimiento de la tuberculosis humana en forma endémica en nuestro país. Es importante resaltar el hecho que se hace necesario complementar esta investigación con el estudio de animales que se encuentran en las fincas tanto positivas como negativas para evidenciar la presencia de animales portadores de micobacterias en forma subclínica que pueden ser los reservorios de estas micobacterias.

Los resultados de esta investigación constituyen temas de interés para el Ministerio de Salud y Protección Social de Colombia puesto que es de su competencia y responsabilidad el control de tuberculosis humana así como la prevención de las zoonosis.

En resumen y partiendo de nuestros hallazgos es recomendable instaurar el programa de vigilancia epidemiológica de la tuberculosis bovina haciendo uso de las metodologías probadas en el presente estudio, inicialmente en los departamentos donde se encontró positividad para M. bovis y/o M. tuberculosis.

En segundo lugar se recomienda realizar estudios más profundos con relación a la presencia de micobacterias del complejo tuberculosis diferentes del M. bovis, como son el genotipo MANU 2 y el T1 tanto en el ambiente silvestre como en los manipuladores de la cadena de producción bovina.

El presente estudio permitió confirmar la circulación en los departamentos de Antioquia, Boyacá, Cundinamarca y Magdalena de al menos 7 genotipos de Mycobacterium bovis causante de tuberculosis bovina en animales provenientes de fincas ganaderas. Está información es útil para los Programas de vigilancia epidemiológica en salud pública y salud animal, direccionado a la articulación de acciones conjuntas que permitan construir marcos normativos para la eliminación y control de la zoonosis, todo lo cual contribuye al mejoramiento de la competitividad en la cadena de producción bovina, y que repercutirá en el cumplimiento de los estándares zoosanitarios internacionales para incrementar el acceso a mercados mundiales, el mejoramiento de la economía del país y el beneficio directo a la salud pública.

\section{Agradecimientos}

A todo el personal que trabaja en el Programa Nacional de Prevención y Control de la Tuberculosis Bovina y la Brucelosis del ICA en Colombia, por su acompañamiento a las zonas de muestreo. 


\section{REFERENCES}

1. De la Rúa D. Human Mycobacterium bovis infection in the United Kingdom: Incidence, risks, control measures and review of the zoonotic aspects of bovine tuberculosis. Tuberculosis 2006; 86(2):77-109.

2. Müller $B$, Dürr $S$, Alonso $S$, Hattendorf J, Laisse C, Parsons S, et al. Zoonotic Mycobacterium bovis- induced tuberculosis in humans. Emerg Infect Dis 2013; 19(6):899-908.

3. Anaelom NJ, Ikechukwu ON, Sunday EW, Nnaemeka UC. Zoonotic tuberculosis: A review of epidemiology, clinical presentation, prevention and control. J Public Health Epidemiol 2010; 2(6):118-24.

4. Instituto Colombiano Agropecuario ICA. Estadísticas del Programa de Tuberculosis y Brucelosis [en línea] 2014 [Ultimo ingreso Octubre 14 2014]. URL disponible en: http://www.ica.gov.co/getdoc/e3fc207fc332-4e38-a50d-de61c338ace6/Campanade-erradicacion.aspx

5. Bennett RM. Farm costs associated with premovement testing for bovine tuberculosis. Vet Rec 2009; 164(3):77-79.

6. Schiller I, Oesch B, Vordermeier H.M., Palmer M.V., Harris B.N., Orloski K.A., et al. Bovine Tuberculosis: A review of current and emerging diagnostic techniques in view of their relevance for disease control and eradication. Transbound Emerg Dis 2010; doi:10.1111/j.1865-1682.2010.01148.x

7. Departamento de Planeación Nacional DPN. Consejo Nacional de Política Económica y Social. CONPES 3376. Política sanitaria y de inocuidad para las cadenas de la carne bovina y de la leche. [en línea] 2010 [Ultimo ingreso Octubre 1 2014]. URL disponible en: http://www.ica.gov.co/ getattachment/3b31038a-72ba-40f9-a34dcecd89015890/2010cp3676.aspx.

8. Departamento Administrativo Nacional de Estadística DANE. Encuesta de sacrificio de ganado. [en línea] 2014 [Ultimo ingreso Abril 30 2015]. URL disponible en: http:// www.dane.gov.co/index.php/agropecuarioalias/estadisticas-de-sacrificio-de-ganadoesag.
9. Zumárraga MJ, Soutullo A, García MI, Marini $\mathrm{R}$, Abdala A, Tarabla $\mathrm{H}$, et al. Detection of Mycobacterium bovis-infected dairy herds using PCR in bulk tank milk samples. Foodborne Pathog Dis 2012; 9(2):132-137.

10. Medeiros Ldos S, Marassi CD, Figueiredo EE, Lilenbaum W. Potential application of new diagnostic methods for controlling bovine tuberculosis in Brazil. Braz J Microbiol 2010; 41(3):531-41.

11. Silva MR, Rocha Ada S, da Costa RR, de Alencar AP, de Oliveira VM, Fonseca Júnior $\mathrm{AA}$, et al.Tuberculosis patients coinfected with Mycobacterium bovis and Mycobacterium tuberculosis in an urban area of Brazil. Mem Inst Oswaldo Cruz 2013; 108(3):321-327.

12. Taylor GM, Worth DR, Palmer S, Jahans K, Hewinson RG. Rapid detection of Mycobacterium bovis DNA in cattle lymph nodes with visible lesions using PCR. BMC Vet Res 2007; 3:12. doi:10.1186/17466148-3-12

13. Miller S, Sweeney S. Mycobacterium bovis (bovine tuberculosis) infection in North American wildlife: current status and opportunities for mitigation of risks of further infection in wildlife populations. Epidemiol Infect 2013; 141(7):1357-1370.

14. Tadayon K, Mosavari N, Feizabadi M. An epidemiological perspective on bovine tuberculosis spotlighting facts and dilemmas in Iran, a historically zebu-dominant farming country. Iran J Microbiol 2013; 5(1):1-13.

15. Thakur A, Sharma $M$, Katoch $V$, Dhar $P$, Katoch R. Detection of Mycobacterium bovis and Mycobacterium tuberculosis from Cattle: Possible Public Health Relevance. Indian J Microbiol 2012; 52(2):289-291

16. Rodwell TC, Kapasi AJ, Moore M, MilianSuazo F, Harris B, Guerrero LP, et al. Tracing the origins of Mycobacterium bovis tuberculosis in humans in the USA to cattle in Mexico using spoligotyping. Int J Infect Dis $2010 ; 14(\mathrm{~S} 3)$ :e129-e135. 
17. Instituto Colombiano Agropecuario ICA. Sistema de vigilancia epidemiológica del ICA tuberculosis y brucelosis. [en línea] 2014 [Ultimo ingreso Octubre 1 2014]. URL disponible en: http://www.ica.gov.co/ Trazabilidad/Normatividad/Files/Resoluciones/ ICA/resolucion-185-de-2007.aspx

18. Silva A del P, León CI, Guerrero MI, Neira R, Arias L, Rodríguez G. Avian tuberculosis of zoonotic importance at a zoo on the Bogotá Andean plateau (Sabana), Colombia. Can Vet J 2009; 50(8):841-845.

19. Organización Mundial de Sanidad Animal OIE. Tuberculosis Bovina. Manual de las Pruebas de Diagnóstico y de las Vacunas para los Animales Terrestres. [En línea] 2008. [Último ingreso Octubre 1 2014]. URLdisponibleen:http://www.oie.int/es/ normas-internacionales/manual-terrestre/ acceso-en-linea/.

20. van Soolingen $D$, De Hass $P E$, Kremer $K$. Restriction fragment length polymorphism (RFLP) typing of Mycobacteria. National Institute of Public Health and the Environment. $2^{\text {th }}$ Ed. Bilthoveen; 2010.

21. Kremer $K$, van Soolingen $D$, Frothingham R, Haas WH, Hermans PW, Martín C, et al. Comparison of methods based on different molecular epidemiological markers for typing of Mycobacterium tuberculosis complex strains: interlaboratory study of discriminatory power and reproducibility. J Clin Microbiol 1999; 37(8):2607-2618.

22. Kamerbeek J, Schouls L, Kolk A, van Agterveld $M$, van Soolingen $D$, Kuijper $\mathrm{S}$, et al. Simultaneous detection and strain differentiation of Mycobacterium tuberculosis for diagnosis and epidemiology. J Clin Microbiol 1997; 35(4):907-914.

23. Brudey $K$, Driscoll JR, Rigouts $L$, Prodinger WM, Gori A, Al-Hajoj S, et al. Mycobacterium tuberculosis complex genetic diversity: mining the fourth international spoligotyping database (SpolDB4) for classification, population genetics and epidemiology. BMC Microbiology 2006; 6:23-40 doi:10.1186/1471-2180-6-23

24. MbDB, M bovis spoligotypes Database. [on line] 2014 [Último ingreso Octubre 30 2014]. URL disponible en: http://www. mbovis.org/spoligodatabase/intro.htm.
25. Allison, P. Logistic Regression, Using the SAS System. SAS OnlineDoc $®$ 9.2. Cary, NC: SAS Institute Inc. 2007.

26. Colombia. Ministerio de la Protección Social. Decreto número 1880 de 2011. Diario Oficial N 48.085 del 30 de mayo de 2011. URL disponible en: http://www.aladi.org/ nsfaladi/normasTecnicas.nsf/09267198f13 24b64032574960062343c/543bd5fa59bed c3a032579de00526b80/\$FILE/Decreto\%20 N\%C2\%B0\%201880-2011.pdf

27. Zumárraga MJ, Arriaga C, Barandiaran S, Cobos-Marín L, de Waard J, Estrada-Garcia I, et al. Understanding the relationship between Mycobacterium bovis spoligotypes from cattle in Latin American countries. Res Vet Sci 2013; 94(1):9-21.

28. de Kantor IN, Ambroggi M, Poggi S, Morcillo $N$, Da Silva-Telles $M$, Osório-Ribeiro $M$, et al. Human Mycobacterium bovis infection in ten Latin American countries. Tuberculosis (Edinb) 2008; 88(4):358-65

29. Hernández-Pando R, Marquina-Castillo $B$, Barrios-Payán J, Mata-Espinosa D. Use of mouse models to study the variability in virulence associated with specific genotypic lineages of Mycobacterium tuberculosis. Infect Genet Evol. 2012;12(4):725-31. doi: 10.1016/j.meegid.2012.02.013.

30. Gumi B, Schelling E, Berg S, Firdessa R, Erenso G, Mekonnen W, et al. Zoonotic transmission of tuberculosis between pastoralists and their livestock in South-East Ethiopia. Ecohealth 2012; 9(2):139-49.

31. Ocepek M, Pate M, Zolnir-Dovc M, Poljak M. Transmission of Mycobacterium tuberculosis from human to cattle. J Clin Microbiol 2005; 43(7):3555-3557.

32. Sanou A, Tarnagda Z, Kanyala E, Zingué D, Nouctara M, Ganame Z, et al. Mycobacterium bovis in Burkina Faso: Epidemiologic and Genetic Links between Human and Cattle Isolates. PLoS Negl Trop Dis 2014; 8(10):e3142. 